nature of things a compromise, and the divergence between the schemes which have been brought torward proves that the reformers are by no means of one mind. The ordinary man does not seem impressed with the necessity for a change. It is alleged that the business man feels some inconvenience, but the English accountant would surely gain far more benefit from a decimal currency than from a fixed almanac. Meanwhile the Board of Trade is very properly taking steps to learn the opinions of the merchants and traders of the country.

It is, of course, mere child's play to invent a calendar. The objection to interrupting the consecutive run of the weeks must be strongly felt. One wonders therefore that none of those who appear to be so much impressed with the advantage of subdividing a year of 364 days have not, so far as we are aware, suggested another plan for getting rid of the superfluous days. This could be done by using the week instead of the day as the unit of intercalation. We begin by allotting 364 days to the common year. We then add at the end of every fifth year (the date ending with o or 5) a special "leap" week. This in itself would make the year on the average too long. We therefore omit the "leap" week every fifty years, when the date ends in 25 or 75 ; and, further, we omit the week at every century which is divisible by 4 (the reverse of the Gregorian rule). The result is to add $7_{\mathrm{I}}$ weeks or 497 davs in 400 years, thus making the average length of the year $365^{\circ} 24^{2} 5$ days, or exactly the same as the mean Gregorian year. The special week would probably be found a nuisance, but it would only come once in five years, and it has been seriously proposed to introduce four such weeks into every year! Of course, under this plan, the date of the equinox would wander eight days on either side of the mean date. At the sacrifice of simplicity it would be more correct to intercalate eleven weeks in each successive period of 62 years, at the intervals :

$$
6,6,5,6,6,5,6,6,5,6,5 \text { years. }
$$

By this rule the equinox would be kept within four days of a given date, while the mean length of a year would be slightly more accurate than in the Gregorian system. Such a variation from the mean date would not be likelv to constitute a practical objection. The idea, however. is only suggested in order to illustrate the unexhausted possibilities which lie before the would-be calendar reformer.

H. C. P.

\section{THE UNVEILING OF NUBIA.}

I ESS than four years ago practically nothing was L known of the true history of that stretch of the Nile Valley, immediately above the First Cataract, which is known to us to-day as Nubia, beyond a few ancient Egyptian stories of raids and conquests, and the tales, often enough fantastic and unreal, of Greek and Roman tourists. In one brief winter's work (rgo7-8) Dr. Reisner and his collaborators have changed all that. For they have recovered from the soil of Nubia the materials for reconstructing the main phases of the history of that country's strange vicissitudes during the last fifty centuries, as well as a great mass of precise information concerning that crucial period in her evolution, when, about twenty-seven centuries before the Christian era, she began to lag behind Egypt and take her own wayward course, which earned for her the ancient byword "wretched" Nubia.

It has now been demonstrated that in predynastic 1 "The Arche logical Sturvey of Nubir. R port for 1907-8." Vol i., Archæelosical Raport. Ry Prof. G. A. Reisner. Pp. v+373+330 textfigures. Plitus and plans to accomonny vol. i. Pp. $24+73$ plates $+x x x$ plans. (Ca:ro: National Printing Denart'nent, Igro.) Pice z l.e.

No. 2 I65, VOL. 86$]$ times, i.e. before Upper and Lower Egypt became united under Menes, the first king of the nrst dynasty (circa $3400 \pm 100$ B.c.), and until the end of the third dynasty (circa 2700 B.c.), Egypt and Nubia were culturally (and, as is shown in vol. ii. of this report, racially also) one territory; but, from the time roughly corresponding to the beginning of the period of the Pyramid-builders in Egypt, the histories of the two countries began to diverge the one from the other, Egypt advancing by rapid strides towards national greatness and the attainment of her highest artistic and architectural triumphs; while Nubia was not able even to maintain the old standard of archaic culture, for her people lost their cunning at the same time that their racial purity became tainted with negro blood.

In the time of the Middle Kingdom (circa 2000 B.c.), when Egypt for a second time was raised on the crest of a wave of prosperity, Nubia also felt the same influence, and began to exhibit marked signs of progress and the attainment of a distinct individuality; then for the first time her people began to manufacture wares that were not merely inspired by Egypt or imitations of Egyptian workmanship, but deserve to be called Nubian. And if it be admitted that the Nubian arts and crafts show obvious traces of their derivation from the archaic Egyptian, it is also clear that they were developed in a manner strikingly different from those found in Egypt in dynastic times. In the first products of these distinctively Nubian arts we can detect, as also in the remains of the people who made them, an underlying stratum of predynastic Egyptian influence, modified by negro admixture, but evolved in a manner quite distinctive of and confined to Nubia.

Egypt and Nubia each went its own way and evolved along the distinctive lines they had respectively chosen, until a time shortly before the inauguration of the New Empire in Egypt. The passing of Egypt under the sway of the Asiatic Hyksos domination had the effect of driving many Egyptians into voluntary exile in Nubia; this led to a displacement of the Nubian population southwards; characteristic Egyptian graves, containing Egyptian wares and the remains of Egyptian people, made their appearance in Nubia at this time; and evidences of Egyptian occupation of the country were abundant throughout the period of the New Empire.

But when Egyptian power began to wane, the Nubians came into their own once more; but as they returned from the south strangers accompanied them, and, ever after this event, from time to time there were incursions of aliens into Nubia; sometimes tall, Dinka-like negroid warriors, with their own distinctive burial customs; later still, Egyptians of the Ptolemaic and Roman periods occupied Nubia and left the characteristic evidence of their stay in the country, as well as the bodies of criminals of non-Nubian type-perhaps the notorious Blemmyes of the Eastern desert, the mysterious people to whom the classical writers so often referredwhom they had executed; then again, in the early centuries of the Christian era, but before the introduction of Christianity into Nubia, another group of Negroes came north into Nubia, and in the graves of their dead buried their own distinctive pottery, which is neither Egyptian nor Nubian; and in Christian times aliens from Syria and western Asia took refuge beyond the First Cataract.

Nubia was ever a poverty-stricken land; to add to her natural disabilities, her geographical position rendered her liable to be overrun by all these alien hordes, and made her the meeting-place of Egrptians and Negroes and the cockpit where they fought. 
This distressful country well earned her ancient title, "wretched Nubia."

In the report of the archæological survey of Nubia there is presented a complete and impartial description of all the historical material thus rescued from the soil, critically sifted, arranged in chronological order, tested by Egyptian criteria, and explained and interpreted.

But in this volume Dr. Reisner has done something more than recover the lost history of Nubia, wonderful as is such an achievement in one short season's work, for he has also given the first adequate and trustworthy account of the earliest stages in the evolution of Egyptian civilisation. It is true that this has often been attempted by other writers : but in all cases fact has been so interwoven with fancy that the pictures painted have been more or less distorted travesties of the truth. Dr. Reisner's report will ever bring the work to the triumphant issue presented in this report. This is no mere idle compliment to Dr. George A. Reisner, assistant professor of Harvard University, who was chosen for this work; for he had a far more exact and intimate knowledge and experience of digging in Egypt such sites as were of crucial importance in Nubia, and had learnt thereby to appreciate the fine distinctions that enabled him to discriminate between archaic burials closely related in time, the one to the other, and to realise the early stages in the divergence between Egyptian and Nubian burial customs before they became obtrusive. It was the possession of this special knowledge that determined the issue in Nubia; and no impartial observer can deny that Dr. Reisner was the man most highly qualified to undertake this work.

No one who was privileged to witness the excavation of the first site dug in the course of this survey

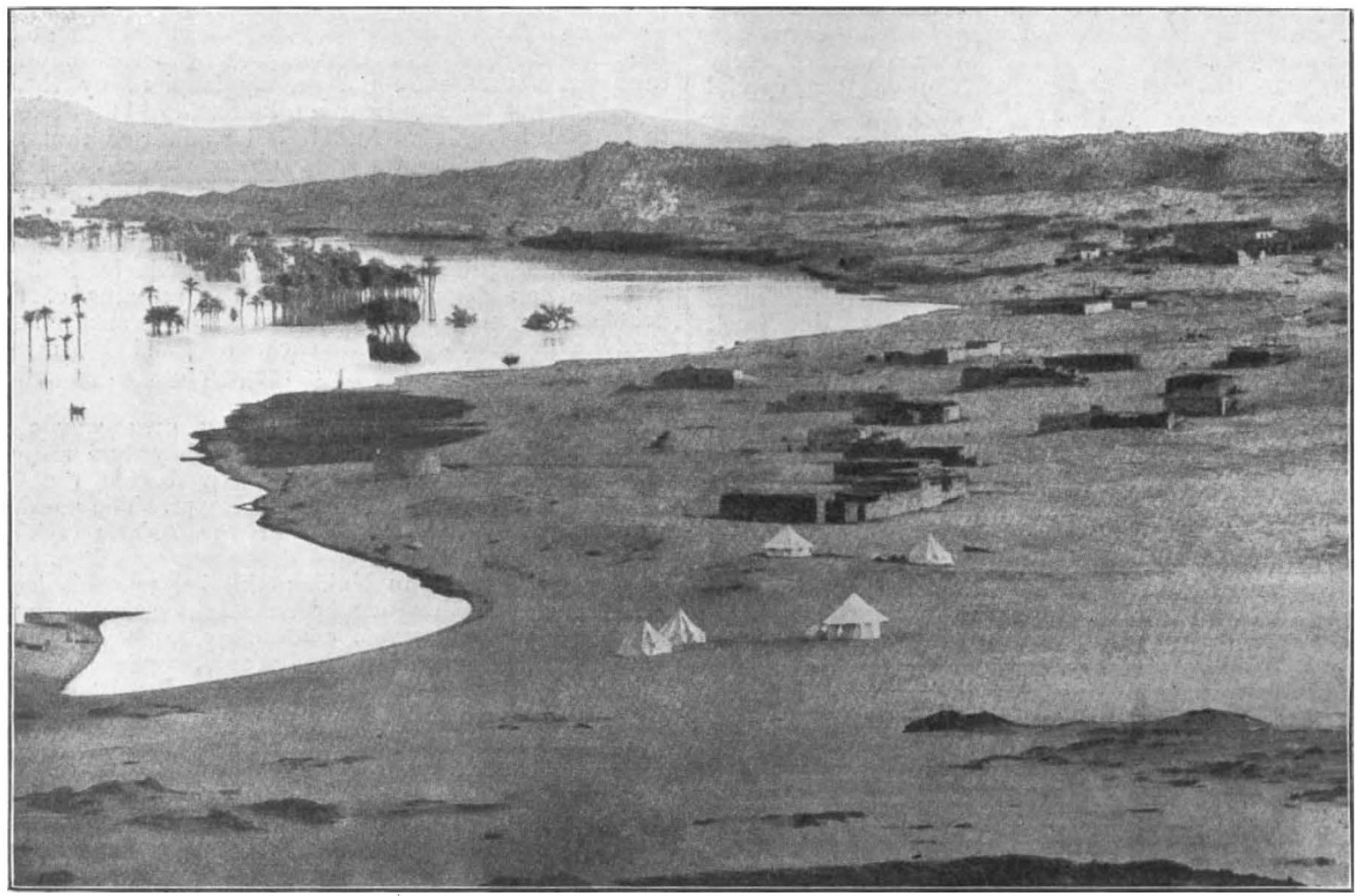

Fig. x.-The aspect of Nubia near Dabod during the inundation by water held up by the Aswan Dam. From "The Archæological Survey of Nubia."

remain a storehouse of accurate information concerning the springs of Egyptian civilisation, and a work of fundamental importance to all students of the beginnings of culture in other lands.

In the preface to this volume Captain H. G. Lyons, F.R.S., formerly director-general of the Egyptian Survey Department, now lecturer in geography at Glasgow University, explains why this survey was undertaken, and describes the measures adopted to make it as thorough and searching as possible; but he does not tell the reader that to him belongs the credit of initiating and organising the excellent plan of campaign in Nubia.

When Captain Lyons was entrusted with the task of arranging for carrying out the proposed survey, he was singularly fortunate in securing probably the only archæologist competent (in the sense that his training and experience specially fitted him to cope successfully with the tangled problems of Nubia) to NO. 2 I65, VOL. 86$]$ (see chapter iv.) can fail to realise the enormous difficulties that had to be overcome before even the alphabet of Nubia's history could be read, and that these difficulties were eventually resolved only by the employment of the most rigorous scientific methods and painstaking analysis of a complicated mass of data, and by the command of an exceptional knowledge and experience to explain them.

In the vast plain surrounding the southern terminus of the Egyptian railroad at Shellal there had been buried the remains of people who had died at every historic period during the last fifty centuries, not only in graves of known Egyptian forms, but in a variety of then unknown Nubian and Sudanese types. Every kind of confusing element was present to complicate the problem: cemeteries of one period intruded in those of earlier date, so that graves of the most varied periods and peoples were apparently inextricably intermingled; the results of the plunder- 
ing of graves, both in ancient and modern times, added to the confusion; and the denudation of the plain by the forces of nature in ancient times had destroyed many, and seriously damaged still more, of the graves. The failure to reduce this chaos to order would have gone far to sterilise the essential work of the survey. The results obtained at Shellal gave Dr. Reisner at the outset the whole history of Nubia in epitome; and all the work since accomplished farther south during the last three years has confirmed the accuracy of the conclusions drawn from the study of "Cemetery vii.," while filling in the details of the story that it summarised.

One of the factors that greatly enhances the significance of this report cannot be appreciated without some reference to Dr. Reisner's work before the Nubian survey began. After acquiring a knowledge of Oriental work in Harvard University, he had studied Babylonian and Egyptian philology and archæology, and contributed to the work of cata-
Dynastic Cemeteries of Naga-ed-dêr, I.," by Reisner, Igo8, and "II.," by Mace, I9I0). It is this fact that renders the Nubian report of such importance, for in the remarkable chapter vii., Dr. Reisner draws aside the veil from his vast storehouse of knowledge of Egypt's archaic civilisation, and gives us more exact and detailed information of the pre- and protodynastic periods in the Nile Valley than has hitherto been published.

Another important factor that contributed in no small degree to the success of the Nubian excavations was the systematic training which Dr. Reisner's native workmen had received during their nine years' association with him in Egypt; each man had learned to do his allotted task as a matter of habit, and each became a specialist in some branch of the work, such as prospecting for sites, excavating, cleaning graves without touching or disturbing their contents, and doing all the routine work of making a complete photographic record of every stage of the survey. In

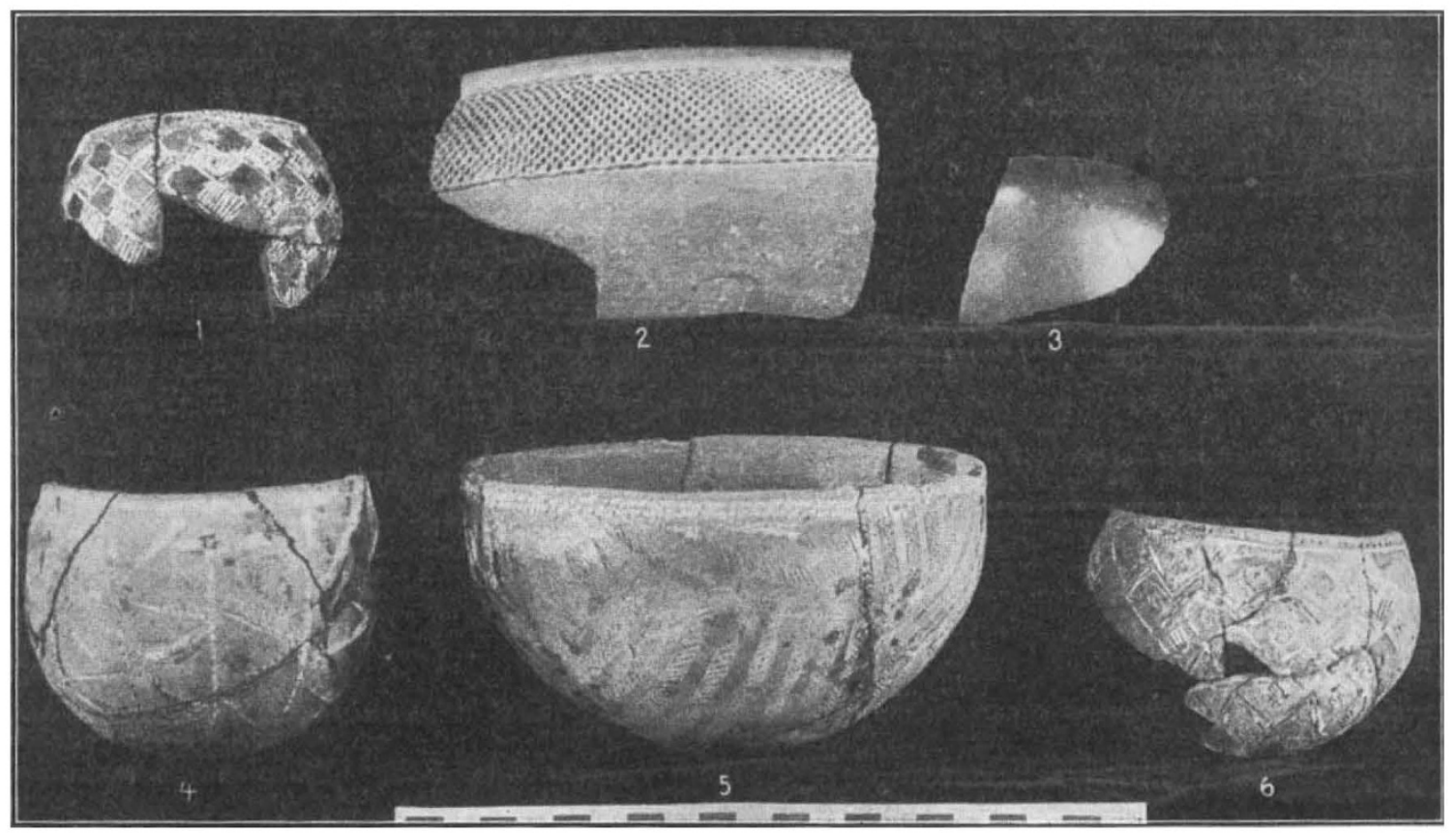

F IG. 2.-The earliest distinctively Nubian pottery. From "The Archaological Survey of Nubia.

loguing the collections in the Berlin and Cairo Museums; then in 1899 he began excavating in Upper Egypt as head of the Hearst: Expedition of the University of California, and in 1903 at the Giza Pyramids, at first for California, but later, from 1905 onward, for the Harvard University and the Boston Museum of Fine Arts.

During these years, 1899-1907, he and his collaborators, Messrs. Lythgoe and Mace, had devoted the whole of their time and energies to the detailed and critical study of remarkably complete series of burials of the predynastic and early dynastic epochs, in the course of which they were able to sweep away a lot of myths concerning the practices of the early Egyptians, which the fertile imaginations of other explorers had created, and to piece together, bit by bit, the accurate information they themselves laboriously gathered. Unfortunately this expedition was so busily engaged in collecting information that its members found time to impart only a very small fraction of their rich harvest to the public ("The Early NO. 2165 , VOL. 86$]$ chapter ii. Dr. Reisner describes these methods, and in the magnificent volume of plates-in itself one of the completest records of archæological research ever issued-will be found ample evidence of the skill displayed by these illiterate Egyptian boys in the practice of the art of photography and the no less difficult task of systematic scientific excavation.

In the work of excavation and the examination and recording of the results, Dr. Reisner was assisted by Mr. Cecil M. Firth and Mr. A. M. Blackman. The major portion of this report consists of their detailed and impartial record of every fact brought to light in the course of their work, illustrated by an exceptionally complete series of photographs and hundreds of text-figures. These results are presented in such a form that anyone who wants to draw his own inferences has all the facts presented to him without bias.

In the last three chapters there is a masterly summary of all the evidence acquired during the first season's work in Nubia, arranged and classified, and 
compared with the collateral data obtained in the course of Dr. Reisner's work in Egypt.

In an appendix Mr. W. H. Crosthwaite describes the topographical work carried on by himself, Mr. T. D. Scott, and Mr. G. W. Murray, and their maps, printed in the Survey Department, appear in the volume of plates.

There are complete lists of cemeteries excavated, graves, objects found, and an index.

This report deals only with the first season's work. During the second season Dr. Reisner had to relinquish work in Nubia in order to take charge of excavations in Samaria and at the Giza Pyramids; but the first winter's work proved to be so illuminating that Dr. Reisner was able to hand over to Mr. Firth, who succeeded him, a knowledge of the history of Nubia, which has amply been confirmed at each new site. This winter the survey will reach Korosko and be brought to a conclusion.

When the final results are published the Egyptian Government may congratulate itself on having provided the means for completing the most thorough archæological examination of such an extensive tract of territory, as Lower Nubia is, that has ever been undertaken.

It only remains to express the hope that the unique collection of antiquities collected with such infinite care and skill, and constituting a tangible record of the history of Nubia, will receive the treatment they deserve.

\section{G. Elliot Smith.}

\section{GERMANY AND THE PROTECTION OF NATURE.}

THE German intellect has a wonderful turn for organic science. Its achievements in this sphere are admittedly unrivalled, and the workers may be counted by the thousand. Such names as Hofmeister, Haeckel, Virchow, Weismann, Sachs, Pfeffer, and Verworn are only a fraction of one per cent. of the list. Consider, for instance, the contributions to a single department, as shown annually in Just's "Botanische Jahresberichte." The typical English attitude, on the other hand, to nature, and especially to organic life, is hardly that of sympathetic study. It may rather be described as amused, or patient, condescension. This patronising habit receives its only modification in the case of "sporting" animals, or the more spectacular birds and mammals; and these are but the materials for a "show," pour passer le temps. The Press pours out a flood of "nature books," as the factories pour out toys, to amuse the children. Popularisation is the curse of the age. An up-to-date book on any branch of organic science is not to be found. Instead of a regular issue of sane, scientific accounts of progress, we have outlines for the use of schools, or productions the aim of which is the titillation or excitement of the unintelligent by means of the illustrations, if it cannot be done by the text. Work that does count appears not more often than once in a decade. It is consequently soon out of date. Such books, moreover, are generally too encyclopædic, and their allocation to different departments is far from being scientifically impartial. The various meanings of the term "nature" supplv a most interesting studv: a corollary may be found in the meanings of the term "natural history." If so vague and obsolete a term is still to be used it should connote the science 1 " $\mathrm{B}$ i rägs rur "at"rdenkmaloflege." Editer bv Prof. H. Conwentz. Erster Bant. Pp. xi+5to. (Berlin Gehruder Borntraeger, rgio.) Price
ro marks.

$$
\text { NO. } 2 \text { I65, VOL. 86] }
$$

of all nature, as did the good old phrase " natural philosophy.'

The practical English instinct also wastes much energy in exploiting the principle of "design" in nature, and in exercising the habit of "drawing a moral." But it is really far more practical to confine the attention to the mechanism of the phenomena, and to leave teleology to metaphysics. Here, and in other matters relating to the study of nature and to the practical application of science, the German intellectual habit can give us a lesson.

It is refreshing to see a great scientific, and veritably practical, movement carried on without any pandering to amusement, pedagogy, or sentimentalism about "nature." This is distinctly the character of the scheme, the progress of which has frequently been noted in these columns, to preserve the natural monuments of Germany. The term comprises the humblest lichen no less than human monuments, such as the Porta Westfalica.

In Prussia the scheme is highly organised and is a State department. Here we see the cooperation of what we should call municipal and district and county councils with, practically, every man of science in the province, and every voluntary society or association. The German Emperor is patron of the committee for the Hohenzollern district. Every square mile of the country is investigated; when anything approaching a "centre," whether geological or ecological, or even for one characteristic species of animal or plant, is: found, that centre receives State protection. The protection, it is well to note, is efficient. The maps printed in the first volume of the "Beiträge" show a remarkable list of such centres reclaimed for nature from man.

This volume of 500 pages records the work done in Prussia during the last five years. The editor, Dr. $H$. Conwentz, has from the commencement been the moving spirit of the scheme, and he is to be congratulated on a remarkable record of success. But, as we have tried to show, the ultimate factor in this success is the German scientific spirit, which here has the advantage of cooperating with patriotism. It will deserve still more of humanity if its example in this matter is able to inspire other countries.

A large proportion of the volume is occupied by reports, now collected, which were noticed in NaTurE on their first appearance. The most noteworthy of the new matter is a long and very interesting account of the parallel movement in Denmark, with which the distinguished botanist, Prof. E. Warming, has had much to do. Even a country like Denmark is full of interesting centres of wild nature. The protected colony of Sterna anglica is particularly noticeable. The lengthy report of the second conference for Naturdenkmalpflege in Prussia, held at the end of 1909, reveals a remarkable combination of enthusiasm and organisation. What especially appeals to us in the whole scheme is its thoroughness and comprehensiveness. We read of a score of "bird reservations," and we find that the protection is more than a mere name. We also read-and to the English mind it reads very strangely - of State-protected wild flowers. Of protected landscapes, "beauty spots," Prussia has about forty: bits of geological interest number, so far, about thirty. What are significantly styled the "remains" of the plant-world and the animal-world are fairlv numerous, but we should suppose the lists to be capable of considerable extension. The foreign reader mav desiderate the Latin name in every zoolngical and botanical species cited. This is not always given, and the disentangling of identity from popular German terms is not easy. 